\title{
Evaluation of Physicochemical Parameters and Microbiologics of Smoked and Frozen Fish available in Korhogo city of Cote d'Ivoire
}

\author{
Kokora Aya Philomène, Cissé Mohamed, N'Guessan Amoin Elyse and Cissé Mariam \\ Department of Biochemistry and Genetics, Laboratory of Food Microbiology and Biotechnology \\ University Peleforo Gon Coulibaly \\ Korhogo \\ Côte d'Ivoire
}

\begin{abstract}
Smoked fish is an important source of animal protein for Ivorian populations. However, the conditions for smoking and selling these smoked fish do not respect the rules of hygiene. To this end, a microbiological study of 60 samples of smoked fish and 15 fresh fish samples of bonito, a fish closely related to mackerel, taken from four markets in the city of Korhogo was carried out. The average total freshwater Mesophilic Flores of fresh fish was $1.29 .10^{9} \mathrm{UCF} / \mathrm{g}$ against $16.34 .10^{8} \mathrm{UCF} / \mathrm{g}$ for smoked fish. The average faecal coliforms $\left(1.58 .10^{6} \mathrm{UCF} / \mathrm{g}\right)$ and fungal flora $\left(2.36 .10^{4} \mathrm{UCF} / \mathrm{g}\right)$ of fresh fish are respectively higher than those obtained $\left(3.34 .10^{4} \mathrm{UCF} / \mathrm{g}\right.$ and $1.10^{4} \mathrm{UCF} / \mathrm{g}$ ) in smoked fish samples. The physico-chemical analyzes ( $\mathrm{pH}$ and TE) of these samples revealed that the $\mathrm{pH}$ of the smoked fish is higher than the $\mathrm{pH}$ of the fresh fish while the water content of the fresh fish is higher than that of the smoked fish. These results suggest that efforts need to be made to improve the microbiological quality of smoked fish sold in the Korhogo markets as the smokers do not meet the standards.
\end{abstract}

Keywords: Bonito, Microbiological Quality, Korhogo, Fresh Fish, Smoked Fish.

\section{INTRODUCTION}

The main source of animal protein in Côte d'Ivoire is fish products with an average annual consumption per capita of $15.9 \mathrm{~kg}$. With total domestic demand at 360,000 tonnes, domestic production remains largely insufficient in relation to needs, although it has increased slightly in recent years, from 57000 tonnes (2012) to 66000 tonnes (2013), to 79000 tonnes (2014) and therefore imports of fish products reach 310000 tonnes [1]. This import quantity costs about 196278 million FCFA. In terms of distribution of processed products, the main commodity is smoked fish which represents a little less than $60 \%$, followed by fermented-dried fish which represents $24 \%$, salted-dried fish with $17 \%$ and braised fish with less than $60 \%$ of $1 \%$, according to data published by [1]. Smoking significantly reduces immediate losses after capture to less than $2 \%$ and extends storage times by 1 to 2 months and that smoking is a good method of preservation [1].

However, the handling conditions during the smoking of the sale and conservation of smoked fish are accompanied by a lack of hygiene at the level of the actors of the sector thus increasing the proliferation of ubiquitous and pathogenic germs (flora of weathering) [2]. These germs may present a risk for the consumer because it can be source of several diseases due to the presence of biological hazards (mold, pathogenic bacteria, mycotoxins) and / or chemical (histamine, heavy metals, polycyclic aromatic hydrocarbons ) [3].

In order to evaluate the quality of the fish sold in Korhogo, our study focused on the evaluation of the physicochemical and microbiological quality of smoked fish and fresh fish sold in four markets in the city of Korhogo. 


\section{MATERIALS AND METHODS}

\subsection{Biological Material}

The biological material compound of fresh fish and smoked fish of bonito (Figure 1), a species close to mackerel, purchased in four markets namely the Big Market, Hausabougou market, Sinistré market and Belle-Ville market of the city Korhogo. Samples were taken from sterilized aluminum foil and transported to the laboratory in a plastic container with ice.

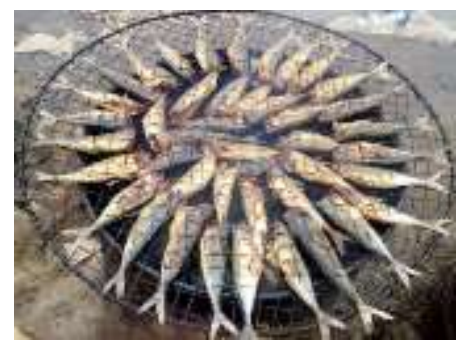

Figure 1: Smoked bonito

\subsection{Investigation}

The survey was conducted using a form. The latter took into account the application of good hygiene practices in the marketing process and in the process of smoking fish in Korhogo. It took place in Korhogo in four (4) markets (Big Market, Hausabougou market, Sinistré market and Belle-Ville market), in these four markets we asked fifty (50) smokers and ten (10) sellers of frozen fish.

\section{SAMPLING PLAN}

The sampling plan included fresh fish and smoked fish. The sampling of fresh fish consisted of taking fresh fish from 5 fresh fish vendors in the large market. Each vendor provided a sample of fresh fish daily over 3 days. The sampling of smoked fish consisted of selecting 5 smokers per market (Big Market, Hausabougou market, Sinistré market and Belle-Ville market). A sample of fish was subsequently collected from each smoker over 3 days. This allowed us to have a total of 15 fresh fish samples and 60 smoked fish samples.

\section{DETERMINATION OF PHYSICOCHEMICAL CHARACTERISTICS}

\section{$4.1 \mathrm{p} \mathrm{H}$}

The $\mathrm{pH}$ of the samples was measured using an electronic $\mathrm{pH}$ meter (Inolab pH 7110 WTW 82362 Wellheim, Germany) immersed in a mixture of $20 \mathrm{~g}$ of ground fish and $80 \mathrm{ml}$ of distilled water [4].

\subsection{Water Content}

The water content is a function of the dry matter content (TMS). The dry matter content is determined according to the standard drying method according to IDF at $102{ }^{\circ} \mathrm{C}$ until a constant mass is obtained [5]. Thus, five grams (5 g) of the sample are weighed in the crucibles and put in an oven at $102{ }^{\circ} \mathrm{C}$ for 48 hours. After drying in an oven, the dry matter content of each sample is obtained by equation 1 :

$\mathrm{TMS}=\frac{\mathrm{P} 1-\mathrm{P} 0}{\mathrm{P}} \times \mathbf{1 0 0}$

- P1 $(\mathrm{g})=$ weight of the sample and the crucible after passage in the oven,

- Po $(\mathrm{g})=$ weight of the empty crucible,

- $\mathrm{P}(\mathrm{g})$ = weight of the sample before passing to the oven;

The water content (TE) itself is determined by equation 2 :

TE $(\%)=100-$ TMS $(\%)$

\subsection{Microbiological Analysis}

The superficial and deep parts of the fish were collected using sterile knives and forceps near a lit Bunsen burner until $25 \mathrm{~g}$ were obtained. The fraction thus collected was used for the preparation of the stock solution [6]. The different dilutions made for enumeration ranged between $10^{-1}$ and $10^{-9}$.

The media used to carry out this work are:

- Buffered peptone water (EPT) for dilutions; 
- Plate Count Agar (PCA), Difco 0479-17-3, Difco Laboratories, Detroit, MI, USA) for the search for total aerobic mesophilic flora according to ISO 4833: February 2003 (incubation time 3 days at $30^{\circ} \mathrm{C}$ );

- Eosin Methylene blue (EMB) for the detection of faecal coliforms according to standard NF V08 - 060 March 1996 (incubation time: $44^{\circ} \mathrm{C}$ for 18 to 24 hours);

- Sabouraud Chloramphenicol agar (BIORAD, France) for the detection of fungal flora according to ISO 21527-1: July 2008 (incubation time: $3-5$ days at $30^{\circ} \mathrm{C}$ ).

\section{METHOD OF INTERPRETING THE RESULTS}

The results were interpreted according to a 3 class plan for total aerobic mesophilic flora, faecal coliforms and yeasts and molds taking into account the following criteria. A sample is qualified:

- $\quad$ of satisfactory microbiological quality (QMS) if the flora $(\mathrm{F})$ is less than or equal to $3 \mathrm{~m}$;

- $\quad$ of acceptable microbiological quality (QMA) if $\mathrm{F}$ is between $3 \mathrm{~m}$ and $10 \mathrm{~m}$

- $\quad$ and of unsatisfactory microbiological quality (QMNS) if $\mathrm{F}$ is greater than $10 \mathrm{~m}$.

$\mathrm{m}$ being the microbiological criterion of Table 1.

Table 1: Microbiological Criteria for Fresh, Frozen and Smoked Fish for Human Consumption.

\begin{tabular}{|l|l|l|l|}
\hline \multirow{2}{*}{ Types of products } & \multicolumn{3}{|l|}{ Microorganisms (CFU / g) } \\
\cline { 2 - 4 } & GAM & CF & FF \\
\hline Fresh fish & $10^{4}$ & 10 & $10^{2}$ \\
\hline Smoked fish & $10^{5}$ & 10 & $10^{2}$ \\
\hline Sources & {$[7]$} & & {$[8]$} \\
\hline
\end{tabular}

\section{RESULTS AND DISCUSSIONS}

\subsection{Results of the survey}

The survey of frozen fish sellers, all men, reveals that $100 \%$ of the frozen fish come from the port of Abidjan. The various fish sold are in $100 \%$ of the cases bonito, horse mackerel, and magne. The best-selling species is bonito. All vendors keep the fish in a cold room with a temperature that varies between -2 to $-15^{\circ} \mathrm{C}$ and when there is a power cut no means is put in place to continue the conservation of fish present in the cold room. And fish of dubious quality are not returned to the port but sold to smokers (Table 2). The observation made on the sales sites and the smoking sites shows that there is a lack of hygiene on the smoking sites compared to the sales sites. The fish are smoked without being eviscerated or salted by the smokers. $100 \%$ of smokers wash their smoking and storage equipment, $44 \%$ of them smoke fish at home and 56\% smoke at a market in a non-hygienic environment. The duration of smoking varies between 2 and 6 hours and the shelf life of smoked fish varies from 2 to 3 days. In case of slump $100 \%$ of the smokers resell the same fish on the markets in order not to lose profit (Table 3 ).

Table 2: Characteristics of fresh fish sale sites in Korhogo

\begin{tabular}{|l|l|l|l|}
\hline Parameters & Number of Vendor & Percentage \\
\hline Gender & Male & 10 & $100 \%$ \\
\cline { 2 - 4 } & Female & 0 & $00 \%$ \\
\hline \multirow{3}{*}{ Smoked fish species } & Bonito & 10 & $100 \%$ \\
\cline { 2 - 4 } & mackerel & 00 & $00 \%$ \\
\cline { 2 - 4 } & Magne & 00 & $00 \%$ \\
\hline $\begin{array}{l}\text { Conservation in case of power } \\
\text { failure }\end{array}$ & $\begin{array}{l}\text { Cold room without other } \\
\text { conservation alternatives }\end{array}$ & 10 & $100 \%$ \\
\hline \multirow{3}{*}{ Return of doubtful cartons } & Yes & 00 & $00 \%$ \\
\cline { 2 - 4 } Freezing temperature & No & 10 & $100 \%$ \\
\hline \multirow{3}{*}{ Potential customer } & -2 à -15 ${ }^{\circ} \mathrm{C}$ & 10 & $100 \%$ \\
\hline
\end{tabular}


Table 3: Characteristics of Korhogo fish smoking sites

\begin{tabular}{|l|l|l|l|}
\hline Parameters & Number of Smokers & Percentage \\
\hline \multirow{3}{*}{ Gender } & Male & 0 & $00 \%$ \\
\cline { 2 - 4 } & Female & 50 & $100 \%$ \\
\hline Pre-treatment of fish & Evisceration & 0 & $00 \%$ \\
\cline { 2 - 4 } & Salting & 0 & $00 \%$ \\
\hline \multirow{3}{*}{ Smoked fish species } & Bonito & 50 & $100 \%$ \\
\cline { 2 - 4 } & Chinchard & 20 & $40 \%$ \\
\cline { 2 - 4 } & Magne & 15 & $30 \%$ \\
\hline Shelf life & 2 days & 30 & $60 \%$ \\
\cline { 2 - 4 } & 3 days & 20 & $40 \%$ \\
\hline Decomposition of smoked fish & No & 40 & $80 \%$ \\
\cline { 2 - 4 } & Yes & 10 & $20 \%$ \\
\hline
\end{tabular}

Good hygiene practices at smoking sites are not respected. There was a garbage dump at the sites (cardboard boxes and packaging bags) and the fish rinsing water remained parked in containers during smoking and often poured into the sites. This lack of hygiene is accompanied by a presence of flies and nauseating odor on smoking sites. After smoking, the fish are sold on stables in the open air without prior hygiene.

\subsection{Physico-Chemical Analyzes}

The results of the physico-chemical analysis are summarized in Table 4.

The $\mathrm{pH}$ results indicate that the $\mathrm{pH}$ of the raw material is $5.98 \pm 0.12$. The average $\mathrm{pH}$ of smoked fish by market varies between $6.056 \pm 0.12$ and $6.19 \pm 0.26$ and is slightly higher than the $\mathrm{pH}$ of the raw material. There is a significant difference at the $5 \%$ threshold between the $\mathrm{pH}$ of the raw material and the $\mathrm{pH}$ of the smoked fish. However, the average $\mathrm{pH}$ of fish in Big Market differs from the average $\mathrm{pH}$ of the Haoussabougou market.

Analysis of the results for the mean water content of the fish samples obtained showed that the TE of the raw material is $69 \pm$ $8.11 \%$. There is an average decrease of 1.27 to $6.87 \%$ of water during smoking. However, this decrease is not significant at the $5 \%$ threshold between raw material and smoked fish in Big Market, Sinistré market and Belle-Ville market. However, it is significant between raw material and smoked fish on the Haoussabougou market.

Table 4: Moisture and pH of samples of fresh and smoked fish by market

\begin{tabular}{|l|l|l|}
\hline Samples & PH & TE (\%) \\
\hline Fisch of Big Market & $6,056 \pm 0,12 \mathrm{ac}$ & $64,8 \pm 6,84 \mathrm{ab}$ \\
\hline Fisch of Haoussabougou market & $6,19 \pm 0,26 \mathrm{~b}$ & $62,13 \pm 4,75 \mathrm{~b}$ \\
\hline Fisch of Sinistré market & $6,17 \pm 0,13 \mathrm{ab}$ & $67,46 \pm 5,78 \mathrm{a}$ \\
\hline Fisch of Belle-Ville market & $6,18 \pm 0,18 \mathrm{ab}$ & $67,73 \pm 3,69 \mathrm{a}$ \\
\hline fresh fish & $5,98 \pm 0,12 \mathrm{c}$ & $69 \pm 8,11 \mathrm{a}$ \\
\hline
\end{tabular}

The XLSTATE 2014 statistical test was used to compare the different means of water content and pH with the 5\% Fisher test. Values that have the same letter in each column are not significant.

\subsection{Microbiological quality of fish samples}

Levels of contamination of fish samples are shown in Tables 5.

\subsection{Mesophilic Aerobic Germs}

The analysis of the results obtained revealed that $100 \%$ of the fish samples analyzed are contaminated by aerobic mesophilic bacteria with an average value of about $1.29 .10^{9} \mathrm{CFU} / \mathrm{g}$ for the raw material and $6.34 .10^{8} \mathrm{CFU} / \mathrm{g}$ for smoked fish samples.

\subsection{Fecal Coliforms}

The microbiological analysis revealed that the average contamination of the raw material is of the order of $1.5810^{6} \mathrm{CFU} / \mathrm{g}$ for $100 \%$ of samples against $3.3410^{4} \mathrm{CFU} / \mathrm{g}$ for $91.67 \%$ of fish samples smoked by fecal coliforms. 


\subsection{Fungal Flora}

The fungal flora is present in 10 samples of raw material that is $66.66 \%$ of contamination with an average value of $2.3610^{4} \mathrm{CFU} /$ $\mathrm{g}$ of sample. For smoked fish samples $86.67 \%$ are contaminated with fungal flora with an average value of $1.10^{4} \mathrm{CFU} / \mathrm{g}$ of sample.

\subsection{Microbiological Quality Of Fish Samples According To Germs}

The microbiological quality of raw material and smoked fish is presented in Table 5. Microbiological analyzes of fish samples showed that $40 \%$ of raw material samples were unsatisfactory for mesophilic aerobic organisms. As for smoked fish, $18.33 \%$ of unsatisfactory samples were observed. For fecal coliforms, there was a higher than standard rate in all samples that constituted the raw material. Thus $100 \%$ unsatisfactory samples were observed against $91.66 \%$ unsatisfactory samples. The fungal flora was responsible for $13.33 \%$ unsatisfactory samples in the raw material against $32.33 \%$ unsatisfactory samples for the smoked fish.

Table 5: Contaminant level of samples by mesophilic flora, fecal coliforms, fungal flora

\begin{tabular}{|c|c|c|c|c|c|}
\hline Studied Flora & Products & $\begin{array}{l}\text { Contamination Level } \\
(\mathrm{N})\end{array}$ & $\begin{array}{l}\text { Number of } \\
\text { Sample }\end{array}$ & $\begin{array}{l}\text { Average } \\
\text { (CFU/g) }\end{array}$ & $\begin{array}{l}\text { Percentage } \\
(\%)\end{array}$ \\
\hline \multirow[t]{2}{*}{ mesophilic flora } & fresh fish & $\begin{array}{l}\text { Absence } \\
\mathrm{F} \leq 3.10^{4} \\
3.10^{4}<\mathrm{F} \leq 10^{5} \\
\mathrm{~F} \geq 3.10^{5}\end{array}$ & $\begin{array}{l}00 \\
02 \\
07 \\
06\end{array}$ & $1,29.10^{09}$ & $\begin{array}{l}00 \\
13,33 \\
46,66 \\
40 \\
\end{array}$ \\
\hline & Smoked fish & $\begin{array}{l}\text { Absence } \\
\mathrm{F} \leq 3.10^{5} \\
3.10^{5}<\mathrm{F} \leq 10^{6} \\
\mathrm{~F} \geq 3.10^{6}\end{array}$ & $\begin{array}{l}00 \\
49 \\
00 \\
11\end{array}$ & $6,34 \cdot 10^{08}$ & $\begin{array}{l}00 \\
81,67 \\
00 \\
18,33\end{array}$ \\
\hline \multirow[t]{2}{*}{ fecal coliforms } & fresh fish & $\begin{array}{l}\text { Absence } \\
\mathrm{F} \leq 30 \\
30<\mathrm{F} \leq 10^{2} \\
\mathrm{~F}>10^{2}\end{array}$ & $\begin{array}{l}00 \\
00 \\
00 \\
15\end{array}$ & $1,58.10^{6}$ & $\begin{array}{l}00 \\
00 \\
00 \\
100\end{array}$ \\
\hline & Smoked fish & $\begin{array}{l}\text { Absence } \\
\mathrm{F} \leq 30 \\
30<\mathrm{F} \leq 10^{2} \\
\mathrm{~F}>10^{2}\end{array}$ & $\begin{array}{l}05 \\
00 \\
00 \\
55\end{array}$ & $3,34.10^{4}$ & $\begin{array}{l}8,33 \\
00 \\
00 \\
91,67\end{array}$ \\
\hline \multirow{2}{*}{ fungal flora } & fresh fish & $\begin{array}{l}\text { Absence } \\
\mathrm{F} \leq 3.10^{2} \\
3.10^{2}<\mathrm{F} \leq 10^{3} \\
\mathrm{~F}>10^{3}\end{array}$ & $\begin{array}{l}05 \\
02 \\
06 \\
02\end{array}$ & $2,36.10^{4}$ & $\begin{array}{l}33,33 \\
13,33 \\
40 \\
13,33\end{array}$ \\
\hline & Smoked fish & $\begin{array}{l}\text { Absence } \\
\mathrm{F} \leq 3.10^{2} \\
3.10^{2}<\mathrm{F} \leq 10^{3} \\
\mathrm{~F}>10^{3}\end{array}$ & $\begin{array}{l}08 \\
16 \\
22 \\
14\end{array}$ & $1.10^{4}$ & $\begin{array}{l}13,33 \\
26,66 \\
36,67 \\
23,33\end{array}$ \\
\hline
\end{tabular}

\section{DISCUSSIONS}

The investigation into the processing, processing and storage conditions of the raw material and finished products of skipjack in the Korhogo markets reveals the impractical hygiene rules. The observation made on the smoking sites shows that the actors have never received training on good hygiene practices. This is due to the unhealthy processing sites that can pose a real risk to fish quality and consumer health. Other authors have made the same observation [2] with the fish Ethmalosa fimbriata and Sardinella aurita smoked and sold in Abidjan and [9], with the Trachurus trachurus fish smoked and sold in the markets of the town of Abomey-Calavi. The results of the microbiological analyzes of the fish samples obtained are in line with the hygienic conditions in which the different actors of the fish sector in Korhogo work. The analysis of our results shows that the average GAM in fresh fish $\left(1.29 .10^{9} \mathrm{CFU} / \mathrm{g}\right)$ is higher than in smoked fish $\left(6.34 .10^{8} \mathrm{UFC} / \mathrm{g}\right)$. These values obtained are much higher than the norm [7]. The same observation was observed by [10]. He got $9.410^{6} \mathrm{CFU} / \mathrm{g}$ for fresh fish and $5.410^{6} \mathrm{CFU} / \mathrm{g}$ during the study of the microbiological quality of horse mackerel (Trachurus trachurus) during the processing smoking. The average mesophilic flora in 
fresh fish can be explained by the poor storage conditions, the storage of fish in poor condition in the same cold room as the fish in good condition. The average total mesophilic flora of smoked fish is greater than the average of 5.4.10 5 germs per product obtained by [11] whose samples come from units that apply good hygiene and manufacturing practices in their process production. These results are consistent with those of [2] who found 3.1.10 ${ }^{7}$ germs per gram of product by working on 150 samples from traditional fish smoking in the Ebrié lagoon in Côte d'Ivoire. The enumeration of the total mesophilic flora is useful in that it makes it possible to define deviations from good manufacturing practices, particularly the delays in the production [12] . Its presence in large numbers indicates the alteration of the product. For fecal coliforms, $100 \%$ fresh fish samples and $91.67 \%$ smoked fish samples are non-compliant with the standard [8]. This result can be explained by the poor hygiene of the various actors (fish sellers fresh and smokers of fish) without forgetting the hygienic state of the sites seen the absence of toilet and adequate system of hand washing. The high contamination of fish by fecal coliforms can be a public health problem because these organisms can sometimes be very pathogenic and can withstand fish [13]. Another reason for the health risk associated with fecal coliforms is the production of histamine, a biogenic amine that is heat-resistant and toxic to humans [14]. Fecal coliforms are germs of fecal contamination and are therefore indicators of poor hygiene conditions when handling fish [13,15]. Fecal coliform contamination may also be related to non-evisceration of fish and non-salting fish prior to smoking.

For yeasts and molds, $66.66 \%$ of fresh fish samples and $86.66 \%$ of smoked fish samples are contaminated with fungal flora. These results are in agreement with those obtained by [9] and [16] who obtained $100 \%$ of analyzed samples contaminated with yeasts and molds. The presence of yeasts and molds may be explained by the duration and conditions of storage, not to mention the exposure to air of the fish during the sale favoring the deposition of spores. Yeasts and molds are germs of deterioration of products causing loss of organoleptic quality and food poisoning (due to the secretion of aflatoxin for example by molds), it is important not to neglect this contamination [9]. The results of the physico-chemical analysis reveal that the water content of smoked fish varies from one market to another. An average decrease of $3.44 \%$ is observed compared to fresh fish due to the smoking temperature. The average water content $(64.8 \pm 6.84 \%, 62.13 \pm 4.75 \%, 67.46 \pm 5.78 \%, 67.73 \pm 3.69 \%)$ recorded in the samples of smoked fish market is higher than that obtained in Nile tilapia (Oreochromis niloticus) smoked $\left(50{ }^{\circ} \mathrm{C}, 10 \mathrm{H}\right)$ in Nigeria which was $45 \%$ [17] and that of $35.5 \%$ in Tilapia spp. Benin in a traditional way [18]. This difference would be explained by the process used, the smoker used, the different fuels used (sawdust, melon shell, rice bran). This high water content could explain the high rate of microorganisms in the fish analyzed. Regarding $\mathrm{pH}$, it is found that the average $\mathrm{pH}$ of smoked fish are higher than the average $\mathrm{pH}$ of fresh fish. However, these values are close to those of a well-preserved dead fish (5.4 to 7.2) [19]. The high $\mathrm{pH}$ values of smoked fish could be explained by the production of basic nitrogen compounds such as ammonia during bacterial growth that indicates loss of quality $[20,21,22]$. In addition, the increase in $\mathrm{pH}$ of a food matrix is related to the decomposition caused by microbial activity [23].

\section{CONCLUSION}

The microbiological analysis of fresh fish samples and smoked fish samples from skipjack, a fish close to maquerau and the bestselling fish in the Korhogo markets, showed a high rate of contamination by fecal coliforms and spoilage germs (mesophilic flora and fungal flora). This confirms that the conditions for the storage, processing and sale of fish do not comply with the rules of good hygiene practice. The high rate of unsatisfied samples and the high water content of fish also indicate smoking conditions that do not meet the standard of production of smoked fish. It is therefore important that bold actions, in particular the use of the dynamic model of 5M (Environment, Raw Material, Material, Workmanship, Method) are implemented to improve the microbiological quality of smoked fish both in production and in production on sale.

\section{REFERENCES}

[1] MIRAH, 2014. Annuaire des Statistiques des Pêches et de l'Aquaculture, Ministère des Ressources Animales et Halieutiques, 36p.

[2] Oulaï. F.S., Koffi. A. R., koussemon. M., Dje. M., Kakou. C. et Kamenou. A. (2007). Evaluation de la qualité microbiologique des poissons Ehtmalosa fimbriata et Sardinella aurita fumés traditionnellement. Microbiol. Hyg, 19, No. $01,55 \mathrm{p}$.

[3] Aké-Assi Yolande., 2013. Doctorante, DVM Attaché de recherche au LANADA Chercheur associé au CSRS Bulletin d'Information du CSRS Nº06 I Décembre 2013, 25 p.

[4] Anihouvi VB, Ayernor GS, Hounhouigan JD, Sakyi-Dawson E, 2006. Quality characteristics of lanhouin: a traditionally processed fermented fish product in the Republic of Benin. African Journal of Food, Agriculture, Nutrition and Development, 6 (1): 1-15. 
[6] Bell. C., Greenwood. M., Hooker J., Kyriakides A., Rebecca. M. (1997). Development and use of microbiological criteria for food. Food Science and Technology Today, $11: 137-176$.

[7] Jouve. J.L., 1996. Qualité microbiologique : Maîtrise et Critères Paris, TEC \& DOC, 2e éd. 563p.

[8] AFNOR. (1996). Analyse microbiologique. T2 : contrôle de la qualité des produits alimentaires- Paris : AFNOR édition, $545 \mathrm{p}$.

[9] Farougou S., Hounkpe E., Sessou P., Yehouenou B., Sohounhloue D., 2011. Evaluation de la qualité microbiologique du poisson trachurus trachurus fumé et vendu dans les marchés de la commune d'Abomey-Calavi. Conférence: Actes du 3 ème Colloque des Sciences, Cultures et Technologies de l'UAC-Bénin, At University of Abomey-Calavi, pp 337-348.

[10] Dègnon R.G., Agossou V., Adjou E.S., Dahouenon -Ahoussi E, Soumanou MM, Sohounhloué CKD. (2013a). Évaluation de la qualité microbiologique du chinchard (Trachuru strachurus) au cours du processus de fumage traditionnel. Journal of Applied Biosciences, Rapport No. 67, pp. 8-10.

[11] Djinou H.P. (2001). Study of the microbiological quality of smoked fish handmade in Cote d'Ivoire for export', Ph.D. Thesis, University of Dakar, 20.

[12] Ababouch L. (1995). Assurance de la qualité en industrie halieutique. Rabat: Ed. ACTES, 214 p.

[13] Degnon G.R., Dougnon T.J., Toussou S. et Migan S.Y., 2012. Evaluation de la qualité microbiologique et physicochimique des poissons capturés et commercialisés au port de pêche industrielle de Cotonou. International Journal of Biological and Chemical Sciences, 6(1): 166-174.

[14] Sitti AH., 2001. Contribution à l'étude de l'évolution de la qualité bactériologique des produits de la pêche de 19972000. Thèse : Méd. Vét : Dakar ; 17.

[15] Bornet, G. (2000). Importance des bactéries psychrotrophes en hygiène des denrées alimentaires, Revue Médecine. Vétérinaire, 151 (11): 1003-1010.

[16] Thiam. A., 1993. Contribution à l'étude de la qualité microbiologique et chimique du poisson braisé-séché (Ketiakh) commercialisé sur le marché dakarois. Thèse : Méd. Vét : Dakar, 15.

[17] Idah P.A. and Nwankwo I., 2013. Effects of smoke-drying temperatures and time on physical and nutritional quality parameters of Tilapia (Oreochromis niloticus). International Journal of Fisheries and Aquaculture, 5 (3): 29-34.

[18] Van den Berghe C., Oliyide A., 1988. Qualité du poisson fumé (Tilapia spp) en fonction des méthodes de transformation et d'entreposage en République Populaire du Bénin. Tropicultura, 6 (2) 51-59.

[19] Love R.M., 1980. Biochemical dynamics and the quality of fresh and frozen fish. In Fish Processing Technology (2nd edn), Hall GM (ed.). Blackie Academic \& Professional (Chapman \& Hall): London; 1-26.

[20] Fan W., Sun J., Chen Y., Qiu J., Zhang Y.and Chi Y. (2009) Effects of chitosan coating on quality and shelf life of silver carp during frozen storage. Food Chemistry, 115(1): 66-70.

[21] Ayala, M.D., I. Abdel, M. Santaella, C. Martínez, M.J.Periago, F. Gil, A. Blanco and O.L. Albors. (2010). Muscle tissue structural changes and texture development in sea bream, Sparusaurata L., during post-mortem storage. LWT-Food Science and Technology, 43 (3): 465-475.

[22] Can ÖP (2011). Combine effect of potassium sorbate and dry salting on the shelf life sardine (Sardina pilchardus). J ournal of Food Science and Technology, 9 (1): 43-49.

[23] Mahmoud B.S.M., Yamazaki K., Miyashita K., Shin I.I and Suzuki T., 2006. A new technology for fish preservation by combined treatment with electrolyzed $\mathrm{NaCl}$ solutions and essential oil compounds. Food Chemistry, 99 (4): 656-662. 